\title{
The Assistance Of Capital Access And Financial Governance On "Fresh Bee" Honey Business In Lumajang
}

\author{
Hesti Budiwati
}

STIE Widya Gama Lumajang

hestibudiwati1404@gmail.com

\begin{tabular}{lll}
\hline Submission : & Review : & Publication : \\
$2^{\text {st }}$ January 2020 & $13^{\text {th }}$ January 2020 & $28^{\text {th }}$ February 2020 \\
\hline
\end{tabular}

\begin{abstract}
Abstrak
The economic development and basic human needs that must be fulfilled triggered the existence of entrepreneurs group, both by productive and non-productive community. In general, because it is managed in a family or household environment, sometimes the management tends to be less serious and confused between family and business finances. From this reason, there was an interest in partnering with a honey business "Fresh Bee" owner namely Bhella Shely Afrilianti in Sumbersuko, Lumajang regency. The partner runs its business to help her family economy. The passion of partner in developing this business should be appreciated, however it requires the ability to face similar business which is quite rife. In raising Klanceng honey requires natural land because this is the advantage of Klanceng bees that its food also naturally sourced so that the honey are very high quality and a great interest to the community. The need for land is what makes this family need capital access to fulfill it. The weakness of partner mostly on financial governance which is still mixed with family finances. The implementation of this community service activity achieved the target, (1) the partner's skill improvement in running its business in sustainable manner, (2) a simple orderly and healthy administration, which mean it is able to separate household and business finances and (3) get capital assistance from financial institutions. The intensive assistance and supervision to the partner need to be done periodically and not stop until the completion of this program. Therefore, the activeness of the team and the ranks of STIE Widya Gama Lumajang community in providing guidance to this partner needs to be carried out continuously.
\end{abstract}

\section{Keywords: Capital, Finances, Management.}

\section{INTRODUCTION}

The economic development and basic human needs that must be fulfilled triggered the existence of entrepreneurs group, both by productive and non-productive community. A family in Sumbersuko sub-district decided to start business by making honey-producing Klanceng bees farms. The Klanceng honey business is called "Fresh Bee" honey owned by Mrs. Bhella Shely Afrilianti, who runs it with her husband, Mr. Fresdi Abraham Hegari. Mrs. Bhella Shely Afrilianti was an employee of private bank in Lumajang, but due to busy caring her childs, she decided to a business that allowed her to be able accompany her childs by still making money for her family. This household business become a target or partner in community sevice activities that carried out by STIE Widya Gama Lumajang lecturer.

Community empowerment through this home industry needs serious attention because it can improve the community's economy. In this regard, Sumodiningrat (2000) explains that 
community empowerment which is characterized by independence can be achieved through a process of community empowerment. This is also supported by the research results of Stel, Carree, Thurik \& Zoetermeer (2004) which state that the role of MSMEs can be said to be very important in the national economy. So support for the existence of this home industry is deemed very necessary. The household industry owned by partners that process honey produced from this klanceng wasp has many benefits of the honey produced. Based on the research of Garedew et al. (2003), Klanceng honey has been shown to have a stronger antimicrobial effect because it contains hydrogen peroxide, phenols, and flavonoids. The advantages of this Klanceng honey will certainly have its own selling value for partners

The passion of partner in developing this business should be appreciated. However, are they able to face similar business competition which is quite rife ? In raising Klanceng honey requires natural land because this is the advantage of Klanceng bees that its food also naturally sourced so that the honey are very high quality and a great interest to the community. The need for land is what makes this family need capital access to fulfill it. The weakness of partner mostly on financial governance which is still mixed with family finances. This skill improvement in financial management and capital access which are offered by STIE Widya Gama Lumajang is expected to be a way out to ensure partner's life sustainability and business development. Therefore, the partner needs to improve the quality of human resources to provide practical understanding about business management to ensure partner's life sustainability. With the assistance on capital access and financial governance offered, it turns out that the partner welcomed and willing to cooperate in this matter.

Based on early survey and situation analysis that have been done, this group has the following problems : (1) Limited capital access, (2) There are no regularly recording or bookkeeping, (3) There are no clear separation between household and business finances.

Furthermore, formal discussions with this partner group showed an agreement that the partners wanted to be able to develop their business and managing their finances well.

solutions offered in service to Klanceng honey business "Fresh Bee" activity owned by Mrs. Bhella Shely Afrilianti : (1) Improve the ability to manage administration and bookkeeping regularly, and be able to separate between household and business finances, (2) Introduce capital access from the financial institutions or government business grant programs.

This community service activitiy is expected to achieve target in accordance with the expectations of partner group, as follows : (1) The partner's skill improvement in running its business in sustainable manner, (2) The orderly and healthy simple administration, which mean it is able to separate household and business finances, (3) Get capital access from financial institutions, (4) This community service activity that involve lecturers is expected become an arena for lecturers in implementing one of the Tri Dharma Perguruan Tinggi namely community service and applying the knowledge they have to share it with the community.

\section{IMPLEMENTATION METHODS Implementation Stages}

How can a partner who have big desire to develop and be able to create jobs for the surround community become the main priority which will be resolved through community service program? The limited ability of partner in managing their business and creating jobs 
for the surround community, become a big problem for the partner so that they need simple solution and able to be reached by them. The STIE Widya Gama Lumajang lecturers who have full support to implement community service activity, trying to provide simple solutions for the partner to develop their business.

The following steps set in order to answer the problem in community service activity :

1. First step, which was agreed to find a solution of the existing problem, included implementing business management activities assistance, financial management and capital access.

2. Second step, which is not less important are the monitoring and evaluation of STIE Widya Gama Lumajang lecturer team to the partner until they can independently run their business well. This monitoring and evaluation not only stop on service period, but it implemented continuously through community service programs that implemented and developed by STIE Widya Gama Lumajang.

All of these stages require assistance that is patient, serious and intensive so that the spirit that has been built does not decline because the challenges in the real competition are not easy, both in terms of marketing, production and management aspects.

\section{Completion Methods}

The implementation methods that will be carried out to solve the partner group problems consist of the following steps :

1. Capital Access Assistance

This capital access assistance aims to introduce partners with official financial institutions in Lumajang to obtain convenience in accessing their capital need.

2. Business Financial Governance Assistance

This business financial governance assistance aim in order that the partners are able to simply managing their business financial and able to separate their business and household finances.

3. Monitoring and Evaluation

Monitoring and evaluation periodically implemented until the partners are able to manage their business financial correctly and continuously so that overall the objectives, targets and outputs of this PKM activity can be achieved properly.

\section{Activity Design}

The first activity was designed by approaching and sharing with partners, because to implement this activity properly will be need full support from they to give understanding of the importance benefits of this community service activity for partner business especially time, energy and mind support where the partners must be focused in implementing this activity and take their time.

The second activity was designed by preparing capital access and business financial governance where it arranged and given by STIE Widya Gama Lumajang lecturers.

The third activity was designed by provide assistance, monitoring and evaluation to helps giving the problems solution until the partners can actually implementing their business financial management properly and continuously. This activity will be held in Mrs. Bhella Shely Afrilia's house as the owner of Klanceng honey "Fress Bee" that located at Haji Sulton Street, Sumbersuko sub-district, Lumajang Regency. 
The fourth activity is preparation activity reports of community service, which is done by compiling a final report and scientific articles to be published on community service journal.

\section{RESULTS AND DISCUSSION \\ A. Problem Solving}

The measure of success of the assistance of capital access and business financial governance on "Fresh Bee" honey business partner in Sumbersuko sub-district, Lumajang regency is the achievement of targets that have been set, as follows :

a. The partner's skill improvement in running its business in sustainable manner.

b. A simple orderly and healthy administration, which mean it is able to separate household and business finances.

c. Get capital assistance from financial institutions.

\section{B. Achieved Outputs}

This community service activity can achieved outputs in accordance with partner's expectation namely :

a. The partner's skill improvement in running its business in sustainable manner.

b. A simple orderly and healthy administration, which mean it is able to separate household and business finances.

c. Get capital assistance from financial institutions.

\section{CONCLUSION}

Several things can be concluded in the implementation of "The Assistance of Capital Access and Business Financial Governance" in Sumbersuko sub-district, Lumajang regency as follows :

1. The program partner having strong desire to expand their business given the tight similar business competition in Lumajang. The limitations in managing their financial and the ability in access to capital become a problem to partner who needs solutions to this activity.

2. The implementation of this community service activity are able to provide simple solutions to expand partner business sustainably and competitive.

3. The achieved targets which is the measure of success of this community service activity is (1) the partner's skill improvement in running its business in sustainable manner, (2) a simple orderly and healthy administration, which mean it is able to separate household and business finances and (3) get capital assistance from financial institutions.

4. This community service activity can achieved outputs in accordance with partner's expectation, namely (1) the partner's skill improvement in running its business in sustainable manner, (2) a simple orderly and healthy administration, which mean it is able to separate household and business finances and (3) get capital assistance from financial institutions.

The toughest challenge for partners is actually when they are truly facing this business competition. Therefore, several recommendations are suggested so this activity can provide sustainable advantages, as follows :

a. The partners must have high passion and will to expand themselves by equipping themselves with increased skills both in ability to innovate and management skills. 
b. The competition that quite tough must be balanced with a positive mentally and attitude, because if the program partner does not have a strong entreprenurship spirit and ability to innovate, they will be easily crushed by the level of similar business competition.

c. The intensive assistance and supervision to the program partner need to be done periodically and not stop until the completion of this program, therefore the activeness of the team and the ranks of STIE Widya Gama Lumajang community in providing guidance to this partner needs to be carried out continuously.

d. It is hoped that the further funding for this activity needs to be implemented to help other similar small businesses so that they are able to innovate and be able develop themselves in increasingly sharp business competition and be able to create jobs for the surround community.

\section{REFERENCES}

Garedew, A., Schmolz, E., dan Lamprecht, I. 2003. The antimicrobial activity of honey of the stingless bee Trigonaspp. Journal of Apicultural Science47(1): 37-48

Stel, Carree, Thurik, Zoetermeer.2004.The Effect of Entrepreneurship on National EconomicGrowth: an Analysis Using the GEM Data-base. SCALES Paper No. 320.

Sumodiningrat, G. 2000. Visi dan Misi Pem-bangunan Pertanian Berbasis Pemberda-yaan. Yogyakarta: IDEA. 